primary and secondary schools, and in the same period 7,000 left the schools. Wastage was greatest among those under thirty, and was also high among untrained graduates under 25. The comparable figure for women was even higher-representing 13 per cent of those qualified and in service, and wastage was again high among untrained graduates. Significant proportions of this wastage could, however, be attributed to transfer from one teaching establishment to another, although among qualified women teachers only 1,000 out of a total of 20,000 transferred in this way.

NUMBERS OF STUDENTS IN COLLEGES OF EDUCATION AND UNIVERSITY DEPARTMENTS OF EDUCATION (other than supple. mentary courses)

Numbers of students

In university

departments of

education

In colloges of

$1956-57$ Oct 1962 Oet 1964 Oet 1965 Oct 1966

education

$\begin{array}{rrrrr}2,512 & 3,260 & 3,739 & 3,695 & 3,192 \\ 26,039 & 47,682 & 62,112 & 72,856 & 84,911\end{array}$

The last page in the report lists the salaries of teachers in colleges of education at March 31, 1966. For male graduates the average salary was $\mathfrak{f 1 , 5 3 9}$

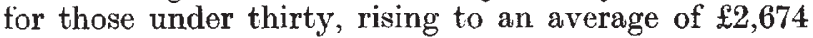
for those aged 60 and over; figures for women graduates were very similar. Male non-graduates received some $£ 100$ less under the age of 30 , and about $£ 140$ less over the age of 60 .

\section{Change on Blood Tests}

THe British Home Office seems to be modifying slightly its attitude to the tests by which motorists in Britain can now be convicted of driving under the influence of alcohol. A recent paper in Nature by Professor J. B. Payne, Dr D. W. Hill and Mr D. G. L. Wood of the Royal College of Surgeons $(21 \%, 963 ; 1968)$ suggests that the methods used by police authorities for carrying out the tests are far from accurate. The method by which the amount of alcohol in the bloodstream is estimated from the amount in the urine seems particularly suspect. So far the Home Office has not been forced to act, because no motorist accused of driving under the influence of drink has quoted Professor Payne's work in his defence.

Although the Home Office has not changed its views on the urine test, there does seem to have been a shift of emphasis in the blood tests. Originally, after advice from the medical associations, police surgeons were advised to take small samples of capillary blood for use in the test, although it was also open to them to take venous blood if they preferred. The work at the Royal College of Surgeons suggests that the latter is likely to give more accurate results, because of the way in which the alcohol tends to become more concentrated in the plasma than in the red blood cells. Blood taken from capillaries can often contain more plasma than blood from veins, so that the capillary method can give anomalously high readings, with the possibility of conviction for a driver who is in fact under the limit.

The Home Office has now sent a circular to police authoritics pointing out that it is within their discretion to take venous rather than capillary blood. The police authorities are advised by the Home Office always to have available a supply of syringes with which venous blood samples can be taken. The motorist can still decide which method he prefers, though the doctor will be at liberty to advise the syringe method if he thinks fit. The circular also points out that the motorist has the right to keep a sample of his own blood for independent analysis, and that these samples should be sealed, stored in a cool place, and analysed with the minimum of delay.

So far, this is no more than a recommendation from the Home Office to the police authorities. Both methods of taking blood are still legal, and the circular says nothing of the inaccuracies of the urine test. But in the event of a driver being acquitted because of the inaccuracies which Professor Payne and his colleagues have discovered, the Home Office would doubtless have to act very much more decisively. Whether the work provides new grounds for appeal for those already convicted under the existing law has yet to be tested, but there is an urgent need to clarify the situation. Sooner or later the Home Office will be forced to set about the task.

\section{Preserving the Bastard Toadflax}

The Nature Conservancy has announced two new nature reserves and an extension to another, bringing the total number of national nature reserves to 124 , covering 257,239 acres.

One of the new reserves is in the central part of the range of chalk hills forming the northern scarp of the Vale of Pewsey seven miles south-west of Marlborough. It is a fine example of unreclaimed chalk downland, and it has long been known to botanists and entomologists for its rich plant and insect life. Extending from Milk Hill in the west to Knap Hill in the east, the reserve covers 188 acres and it has been established by agreement with New College, Oxford, and the agricultural tenant. The summit of Milk Hill $(964 \mathrm{ft})$ is the highest point in Wiltshire. Examples of plants found in the reserve are round-headed rampion, field fleawort, bastard toadflax and several orchids. The Chalk Hill Blue and the Brown Argus are two of the butterflies found. There are also several features of archaeological and historical interest. One of the best examples of a neolithic causeway camp lies on Knap Hill, and there is also a chambered long barrow known as Adams Grave on Walkers Hill.

The other new reserve is at Fbbot Gorge, Somerset,

\section{Sorry, for copyright reasons some images on this page may not be available online}

North part of Hartland Moor, Isle of Purbeck (Crown copyright). 
on the southern face of the Mendip Hills near Wells. It was presented to the National Trust by Mrs Gerard Hodgkinson in 1967 in memory of Sir Winston Churchill and it is being managed by the conservancy under a lease. The reserve covers 101 acres and includes a dry gorge of carboniferous limestone. There are several small caverns in the gorge where the remains of reindeer, bears, wolves and lemmings have been found together with those of Neolithic Man.

The Nature Conservancy has also leased an area of 423 acres on the Isle of Purbeck which increases the Hartland Moor Reserve to 637 acres. The extension is characterized by its fen type vegetation. Black Bog rush occurs in the north-eastern part, while sundews and bladderworts grow on the middle and lower bogs. There are several local plants including the Dorset Heath along the bog edges. The rest of the reserve consists of dry heathland.

\section{Wellcome Initiative}

THE Wellcome trustees announced this week that they are proposing to allocate up to $£ 2.5$ million to medical scientists in universities in Great Britain and Northern Ireland, with the aim of encouraging more high-quality men and women to stay in Britain. The new grants will enable medical research workers to continue their research programmes which might otherwise be threatened. Letters have been sent to vice-chancellors in Great Britain and Northern Ireland asking them to inform the appropriate departments of the proposal. Applications will have to be sponsored by the university concerned, and the final selection will be made by the Wellcome trustees. Each grant will be allocated to meet the special needs of an individual and may be as large as $£ 20,000$ over a period of about five years.

\section{How Children Choose}

Occupations, and the factors which affect children's choices of subjects and careers, were both involved in the Dainton enquiry, because of their effect on the flow of candidates in science and technology into higher education. To provide information on this subject a critical review was commissioned and has now been published (Occupational Choice, J. R. Butler, HMSO, $3 s$. 6d.). Mr Butler, a research fellow in sociology at the University of Manchester Medical Care Research Unit, has reviewed the literature which covers the formation of decisions on occupations in Britain, and summarizes the factors that appear to be most important. Emphasis is laid on science and technology, because of the requirements of the Dainton enquiry, but non-scientific occupations had to be included in the investigations so that the influences working specifically towards occupations in science and technology could be picked out.

The subject is approached from a sociological point of view, in so far as conclusions on occupational choice are assessed in terms of concepts which are linked with sociological or psychological theory; but the pattern of choice which emerges has practical significance. Psychological, motivational, economic and sociological factors work together over a period of several years to predispose an individual towards a particular type of occupation, while his opportunities in other directions become limited by his education.
Scientific interests are often obvious as early as eight or ten, and by the mid-teens the choice between science or arts has usually been made. Because of the way the educational system is organized, revision of choice of occupation becomes less possible as an individual progresses up the school. Although the specialized teaching helps those who have a definite career in mind, it has the disadvantage of setting limits on the choices of those who are uncommitted. Thus the broad area of occupation is often decided early in the school career, while the final decision is a result of interactions between personal and external factors. Personal interests and aptitudes are matched against ideas of the value set on various jobs, orientated towards people, extrinsic rewards or self-expression; external influences such as school, family and social contacts also have their effect. The guidance of parents and friends is believed to be more important than more formal career advice received at school. There are conflicting opinions about the effects on subject choices of personalities of teachers and the ways in which subjects are presented.

Mr Butler's recommendations are put forward as guide lines for future investigators rather than as detailed research proposals. He suggests that a multidisciplinary approach would provide interesting results, and recommends following the progress of a group of children from the age of eight until they enter the labour market. To get the greatest value from such research a comprehensive theory must be developed to test findings. An experimental programme of early and frequent vocational guidance to a group of children might yield valuable results.

\section{Incendiary Statistics}

Fires in Great Britain killed 780 people, three of them firemen, during 1966. This figure is in line with the increase that has, regrettably, been going on over the past six years, but does not reach the abnormally high figure of 818 which was recorded in 1963 , the year of the hard winter. Standing at 165,053 , the total number of fires in 1966 was less than that for any of the three previous years, although the number of fires in buildings, 88,162 , increased as it has done for the past 20 years. The recently published United Kingdom Fire Statistics for 1966 (HMSO, 15s.) gives these figures, and statistical analyses by the Ministry of Technology's Fire Research Station, Borehamwood, of reports of fires attended by the 147 local authority fire brigades. The statistics cover when, where and how fires were started, how they spread, and how they were fought. Details of casualties are also given together with ways of escape of survivors, and correlations of casualties with sources of ignition of the fire.

The number of fires in dwellings seems to be levelling off at about 34,000 a year, putting the rate of incidence at 20 fires per thousand dwellings at risk. The rate of incidence in the distributive trades also appears to be levelling off, but in the manufacturing industries there is still an upward trend. Outdoor fires have been fewer in the past couple of years, but the general trend since 1946 has been upward. Refuse disposal is a particular problem, and fires from this source have more than doubled in the past four years. Although these fires do not cause very much damage, they are expensive in terms of fire brigade time. Smoking 